Barget, Eric and Gouguet, Jean-Jacques. The importance of foreign spectators' expenditure in the tourism impact of mega-sporting events.

\title{
THE IMPORTANCE OF FOREIGN SPECTATORS' EXPENDITURE IN THE TOURISM IMPACT OF MEGA-SPORTING EVENTS
}

\author{
ERIC BARGET \\ Associate professor \\ CDES-OMIJ, University of Limoges \\ eric.barget@unilim.fr \\ JEAN-JACQUES GOUGUET \\ Professor \\ CDES-OMIJ, University of Limoges \\ gouguet@cdes.fr
}

Fecha recepción: julio de 2012

Fecha aceptación: octubre de 2012

\begin{abstract}
Many economic impact studies assessed that mega-sporting events can have an influence on the level of economic activity of the host territory. The attraction of many tourists is usually at the centre of the analysis. During the Rugby World Cup 2007 in France, foreign spectators are at the root of most of the economic impact on French regions, with significant differences depending on their nationalities and their sociodemographic profiles. It thus appears that the regional impact of the event is even stronger since the host matches have attracted many foreign spectators with a high level of income and expenditure.
\end{abstract}

KEY WORDS: Mega-sporting events, economic impact, tourism benefits, expenditure profile, base theory.

JEL: L83.

\section{INTRODUCTION}

It is generally considered that mega-sporting events can generate significant economic impact on host territories, especially through the arrival of many tourists. However, the economic analysis of this impact is still subject to much debate, firstly because of the wide variability of results depending on the model that is implemented, secondly with respect to the political use of such results. Most of the time, in the preparation stage of hosting a mega-sporting event, we observe the preeminence of the calculation of economic impact to justify this decision. However, there is a consensus in the scientific community of sports economists to recognize that the legitimacy of an event organization cannot rely on the calculation of the economic impact only (Kesenne, 2005; Baade, 1996; Martin, 1991). This requires also a calculation of social profitability (costs/benefits). 
Barget, Eric and Gouguet, Jean-Jacques. The importance of foreign spectators' expenditure in the tourism impact of mega-sporting events.

Two calculations should then be made: A calculation of economic benefits to measure the knock on effects of sports entertainment in the territory; a calculation of social utility which consists in measuring the net social benefit or the net social loss generated by the event. These two calculations are complementary: the cost-benefit analysis provides an answer to a problem that was not considered by the calculation of economic impact, and vice versa. The impact study concentrates on visitors and financial flows from outside the host territory (base theory); the cost-benefit analysis focuses on the welfare of the host country inhabitants. These two calculations are complementary for the improvement of the decision-making process. Indeed, the objectives of the decision-maker may be multiple: improve the welfare of its population, economic development, improvement of brand image, of identity, of attractiveness of its territory.

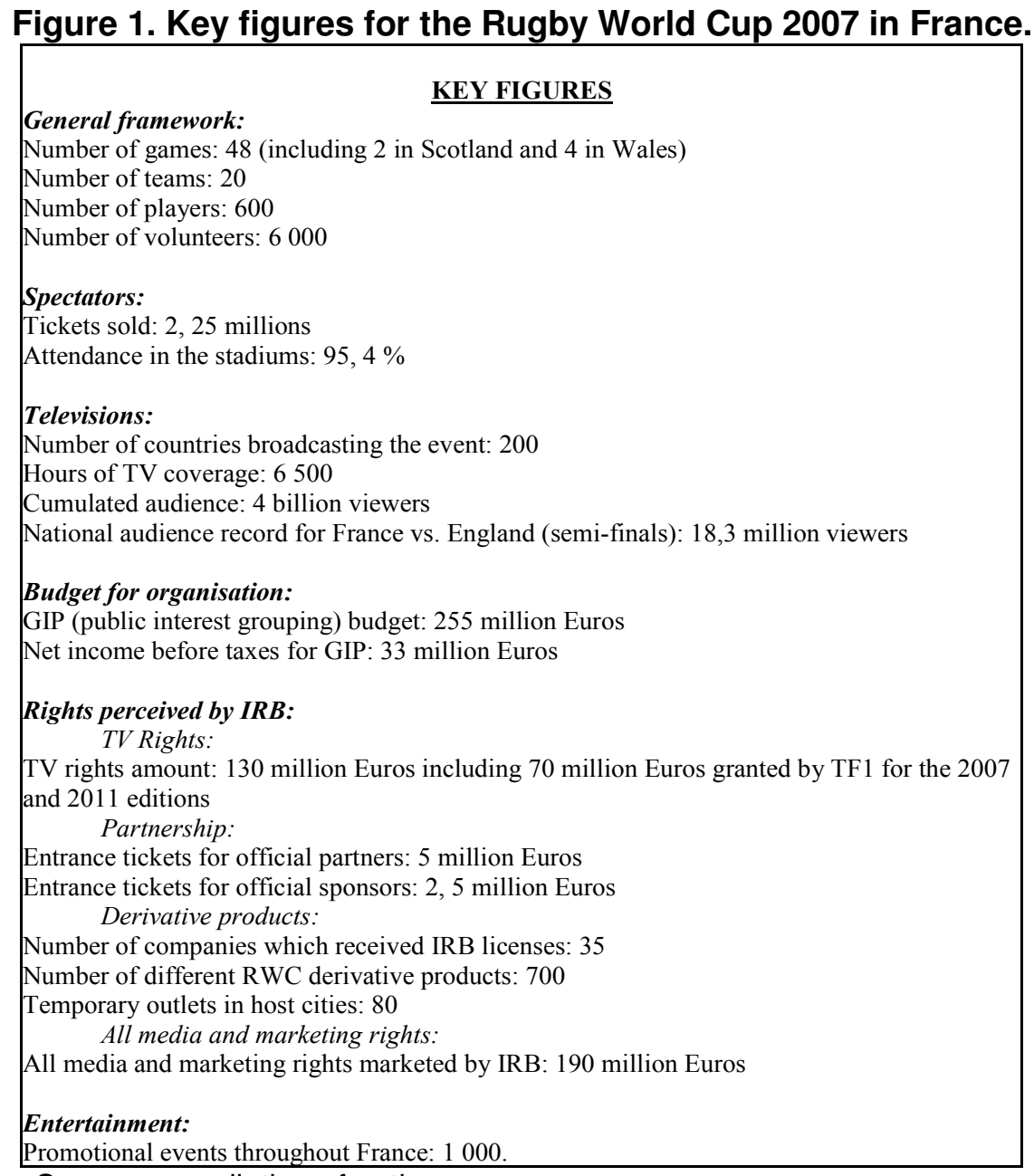

Source: compilation of authors.

As part of this article, we will stick to the calculation of the short term impact of a mega-sporting event: Rugby World Cup 2007 in France. Beyond the very optimistic results of the studies conducted before the event (ESSEC, 2007; MKG Hospitality, 2007), it seems important to think about their conditions of validity. This is why, instead of an ex-ante study that is still very unstable, we preferred to conduct an expost analysis of the Rugby World Cup to assess in particular its tourism impact. The Rugby World Cup is an atypical event compared to other worldwide events like the Olympic Games. Indeed, it can be considered as a mega-sporting event at a global 
Barget, Eric and Gouguet, Jean-Jacques. The importance of foreign spectators' expenditure in the tourism impact of mega-sporting events.

scale given its media coverage and audience (see figure 1). However, its organizational arrangements (its significantly lower budget compared to other megasporting events, limited investments, etc.) as well as the craze for rugby being only concentrated in a few countries at the international level tend to mitigate the place of the Rugby World Cup as a mega-event.

The Rugby World Cup raises a difficulty of analysis specific to multi-site events. It was hosted by ten cities and eight French regions which catched economic benefits that are interesting to analyze both in their extent and structure to display regional specificities:

- What are the factors explaining regional differences in the extent of the economic impact of the Rugby World Cup? ;

- What is the place of foreign tourists' expenditure? ;

- Are there significant differences according to the nationality of tourists?

To answer these questions, the second section presents through a literature review, the methodological framework of the tourism impact measurement of mega-sporting events. A third section presents the conditions for implementing the impact calculation in the field. A fourth section comments and discusses the results. A fifth section concludes.

\section{METHODOLOGICAL FRAMEWORK}

\subsection{Two approaches: social profitability and economic impact}

There are two main methods to comprehend the effects of a project in general, of a sporting event in particular, in the territory: the first one is the calculation of social profitability (Barget \& Gouguet, 2010a) the other one is the economic impact (Barget \& Gouguet, 2010b). We will present the main features of these methods which rely on different paradigms (welfare theory for one, regional economic development for the other) and do not aim at measuring the same type of economic effects.

\subsubsection{Social profitability}

The theory of welfare (Mankiw, 1998) provides several tools for evaluating projects to assess the change in collective welfare that will result from it. All these tools are from the Welfare Economics and represent the economic calculation (Perret, 2004). This involves comparing the resources mobilized by a project (costs) and the results obtained (benefits), and on this basis, make choices between alternative projects. In a world where resources are relatively scarce, decisions of policy makers in the allocation of common resources can be enlightened by the economist, on the basis of the increased satisfaction of the community provided by various projects. The approach is normative as it aims to help policy makers to make choices in the use of public funds. The concept of opportunity cost is central, the money used for a project is no longer available for another; the profits that this alternative project (which had to be abandoned) would have generated were lost, they represent the opportunity cost of the chosen project (Preuss, 2007a).

The methods all proceed in the same way, however they do not all go as far in the recognition and promotion of benefits and costs of public projects. The balance of Papeles de Europa 
Barget, Eric and Gouguet, Jean-Jacques. The importance of foreign spectators' expenditure in the tourism impact of mega-sporting events.

costs and benefits associated with each project follows procedures and takes various forms: the cost-effectiveness analysis, the cost-utility analysis and the cost-benefit analysis. The distinction between these approaches focuses on the issue of monetarisation of benefits and costs. The cost-benefit analysis goes further than the cost-effectiveness and costs-utility analysis, by allowing the calculation of gain or net monetary loss for the community. This approach proceeds to the monetarisation of all benefits and cost of competing projects. It is possible, by using this method, to achieve a classification of projects as they are more or less desirable for society, based on the criterion of net social benefit or net social loss (difference between benefits and costs). The costs-effectiveness analysis comprehends the consequences of projects in terms of physical units (the most appropriate ones): a predefined set of objectives is specified. Indeed, on two projects, we will choose the one that can achieve these objectives at the lowest cost. The aim is to achieve a given efficiency while minimizing costs or, conversely, to achieve maximum efficiency for a given cost. The costs-utility analysis does not just understand the results of the project in terms of physical units, but it assigns "utilities" to these physical units. As part of the Rugby World Cup, we kept the cost-benefit analysis, the most successful one, from our point of view. The results have been published elsewhere (Barget and Gouguet, 2010d); and are not included here.

\subsubsection{Economic impact}

The economic impact study relies on regional economic development theories. It attempts to quantify the economic consequences of an ongoing activity (a military base, sports equipment, etc...) or temporary activity (a festival, sporting event, etc...) in a given territory (Jeanrenaud, 1999). It helps to explain inequalities in regional development. It is thanks to the efficiency of the method that the economic impact calculation has been a tremendous success over the past 40 years. Regarding sporting events, the overall objective is to show how they affect economic activity in the host territory, by mobilizing aggregates such as value added, employment or additional tax income.

There is no standard calculation of economic impact; works in sport as well as in other fields are particularly heterogeneous. Divergent angles of observation are selected from one study to another. The researcher may attempt to report changes in economic aggregates occurring in the short period (during the event) or, on the contrary, in the long term (before, during and after the event), which raises the question of the choice of time horizon. It may proceed to the evaluation of effects at different spatial levels, from the town to the State, which led to reflect on the notion of relevant space for the calculation of impact (Dion, 1987). Besides the choice of the aggregate and of the territory of analysis, the researcher may be interested in the production of additional revenues or redistribution of income within the territory. The wide variety of motivations and observation angles underlying economic impact studies explains the multiplicity of the models used, these ranging from econometric analysis to the use of sophisticated macroeconomic models, via the use of more or less disaggregate multipliers. In this article, we will focus on this latter approach, which is also the most common. Based on an injection that corresponds to the direct and indirect effects, secondary effects can be calculated by applying a multiplying coefficient which reflects the successive rounds of expenditure and income in local space.

Papeles de Europa

25 (2012): 27-50

Doi: http://dx.doi.org/10.5209/rev_PADE.2012.n25.41094 
Barget, Eric and Gouguet, Jean-Jacques. The importance of foreign spectators' expenditure in the tourism impact of mega-sporting events.

The search for commonalities between the different studies reaches quickly its limits; economists comprehend the sport entertainment only through some of its benefits and fail to have a complete view of this economic phenomenon. This observation was made by Davidson (1999), who expresses it in a figurative way. Thus, the economist in charge of an impact study would be like an ant on an elephant. Depending on the chosen observation point, he could scientifically draw very different conclusions from the subject of the study, without ever managing to have a full representation. Moreover, economic impact studies only consider benefits and ignore costs and some (Stringer, 1993) even transform costs into benefits. This is a major difference with the cost-benefit analysis; the result is a potential risk of bias in favour of major projects that are very expensive. The impact study under these conditions cannot in itself constitute an instrument to legitimize the decision to host an event (Jeanrenaud, 1999; Barget and Gouguet, 2010c). From this point of view, the measurement of economic benefits of sporting events is a highly controversial topic. Within the scientific community, many are speaking out (economists, statisticians, etc.) to say these are "etudes-alibis" that give systematically significant economic benefits and incorporate methodological errors leading to results that are often largely overestimated (Barget and Gouguet, 2010a).

The results regarding economic benefits are very often retained in the decisionmaking process, and a strong social demand for this type of studies is noticed. It can be explained by the fact that jobs and incomes generated are an essential reason for the acceptance of the project (and of inherent costs) by the population. The emphasis is frequently put on the challenges for the tourism industry, which is not surprising since, if events give rise to investments and variable organizational costs (sometimes limited) they always cause mass displacements of supporters. The assumption that sport entertainment could influence the tourism economy is largely used by policymakers who engage real strategies for systematically hosting sporting events which tourism development is a major objective (Chappelet, 2006; Teed, 2006). One of the main characteristics of sport entertainment, which has also been widely used by economists to define the notion of hallmark events (Ritchie and Yangzhou, 1987), is their strong attractiveness. Tourism impact can then be defined as the result of visitor expenditures (fans attending the event and accompanying persons, athletes and their staff, officials and VIPs). Here we will deal with the tourism impact of the Rugby World Cup 2007, in accordance with the true culture of impact calculation existing in the tourism sector (Madden, 2002 ; Preuss, 2007b ; Li and Blake, 2009). In comparison, when we speak about the economic impact, we think about the benefits linked to the visitors' expenditures, but also about the organizational costs (organisation committee) and investments (mainly public).

\subsection{Instruments of impact calculation}

Two types of models seem to emerge in recent years to make the tourism impact calculation of mega-sporting events: the input/output model and the computable general equilibrium models (Kasimati, 2003). Given the difficulties associated with their operational implementation we opted for the model of the economic base which is more suited to the French case. 
Barget, Eric and Gouguet, Jean-Jacques. The importance of foreign spectators' expenditure in the tourism impact of mega-sporting events.

\subsubsection{Input-output}

The Leontief multiplier (or input-output) is a fully disaggregate approach that identifies the knock-on effects of the initial shock in the demand side on the different sectors of the economy. The disaggregate nature of the method makes it particularly suitable for the analysis of specific activities, such as occasional sporting events which have huge effects on the construction industry (in terms of investments) and tourism (fans expenditure). The regional economic structure must first be fully reconstituted by identifying inter-industrial relations and the establishment of an input-output table: as many sectors as the data allow are identified. For each, we must establish what are the inputs used in the production process and determine how the outputs (production) will be divided between intermediate consumption of businesses and final consumption of individuals. From the knowledge of these interindustrial relations, it is possible to estimate the total sectoral changes of the production needed to meet the demand originally born in only one of these sectors. (Blake, 2005).

This approach is attractive by its disaggregate nature, especially since it is possible to divide the benefits according to their territorial distribution, or to the occupations and social categories of beneficiaries. However, the model is very demanding in information as all the inter-industrial relations and inter-regional trade must be known. It is therefore a relevant choice for countries with a significant level of advancement of regional economic statistics, mainly Anglo-Saxons countries (Porter and Fletcher, 2008; Dwyer et al., 2003).

In other countries, we rely more on multipliers or regional macroeconomic models, the base theory or Keynesian-type multipliers are generally retained.

\subsubsection{Computable general equilibrium model}

As recalled by Blake (2005) computable general equilibrum models (CGE) have been used in a wide variety of fields ranging from international trade to agricultural, economic development and environmental protection policies, and more recently in the tourism sector. These models incorporate key relations that are not considered in the input-output model (figure I-29, in Blake, 2005). They are increasingly popular for economic impact studies of sporting events, which can be explained by the fact that these are sophistications of the input-output model.

The computable general equilibrium model introduces the effects on prices which are assumed constant in the input-output approach, while acceleration in inflation is inherent to mega-sporting events. It should also be recalled that CGE models impose constraints on the availability of production factors (labour and capital), so that, depending on the scenario chosen, the supply of these factors is either fixed or variable; the supply of factors answers to price changes rather than assuming they are available in unlimited quantities to meet demand. The supply of production factors is no longer assumed to be perfectly elastic. Where the input-output model adds the direct, indirect and induced effects of tourism and leads to a tourism multiplier in general greater than one, the CGE model incorporates the resource shifts that may occur between tourism and other economic sectors. 
Barget, Eric and Gouguet, Jean-Jacques. The importance of foreign spectators' expenditure in the tourism impact of mega-sporting events.

There may be a decrease in production of others sectors. CGE models include the fact that resources (input or intermediate consumptions) can simply be moved from the other sectors of the economy to tourism (Copeland, 1991). Unlike the inputoutput approach, the result of the study can be negative in some sectors.

Thus, CGE models are supposed to provide more realistic results, yet their validity depends on strong assumptions (Blake, 2005; URS Finance and Economics, 2004). As well, there may be a gap between the sophistication of these models and the local reality, which led us to prefer the base theory.

\subsubsection{Economic Base Theory}

When we speak of economic base, we generally seek to determine the economic potentialities of a territory which are the most fundamental for the development of these units (Davezies, 2008; Gouguet, 1981). These are basic activities, the other ones are induced. So here we have a dichotomous theory of growth because of the recognition of two distinct types of activities. The sporting event can be seen as a basic activity (Bourg and Gouguet, 1998). This theory seems particularly suited to small territories like those of the Rugby World Cup. Mega-sporting events, considered as basic activities, are a leading factor for economic growth in these areas. Indeed, they raise money in the concerned territories, and by a multiplier effect, will generate a creation of value added and employment (see figure 2).

Figure 2: Overview of the economic impact calculation of a sporting event.

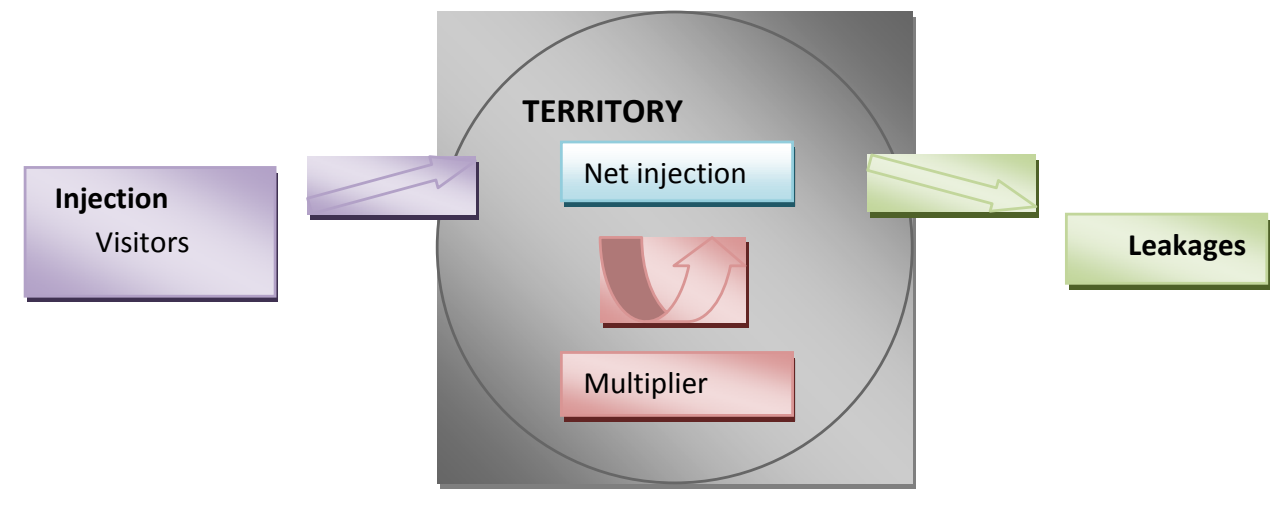

Economic benefits $=$ Net injection $\mathbf{x}$ Multiplier

- Leakages

Source: authors.

However, if the base theory is relatively simple in principle, it presents difficulties in its implementation which can lead to mistakes, if we are not careful. On small territories, the extent of the impact will depend on two factors: the size of the project and the degree of integration of the territory around its productive structure.

The size of the project often determines the use of external specialized operators. Large projects on small territories often benefit to the outside. As to the degree of integration of the territory around its productive structure, the stronger the degree of integration is, the smaller the leakages will be (see the example of the Olympic 
Barget, Eric and Gouguet, Jean-Jacques. The importance of foreign spectators' expenditure in the tourism impact of mega-sporting events.

Winter Games in Albertville). The smaller the region is, the less diversified and integrated it will be. The greater the leakages may be, the lower the multiplier will be. When it comes to the calculation of such a multiplier, Anglo-Saxons researchers are favored by the degree of achievement of their regional economic accounting system. Existing statistics in inter-industry relations and inter-regional trade enable the construction of regional input-output matrices and the disaggregate simulation of regional impact. In France, there is no such thing, and we need to settle for the calculation of aggregated multipliers of income, since disaggregate multipliers of expenditure according to the categories of agents involved would require long and costly field surveys. Here, it was desirable to calculate a multiplying coefficient on the same basis for all the eight host regions, for purposes of comparability and equity in the treatment. More specifically, the multiplying coefficient was calculated from the meta-analysis suggested by Vollet and Bousset (2002) whose estimation we have used here:

$$
(5)^{k=}=0,53+0,17 \ln P O P-0,025 \ln P R T+0,083 \ln T E R
$$

The positive relationship between population size (POP) and the value of the multiplier demonstrates the influence of the degree of diversification of the regional structure. We can assume that the bigger (and diversified) the region is, the lower will be the propensity to import, and the higher will be the local propensity to spend, which explains the high value of the multiplier.

The impact of the workforce structure on the multiplier value confirms the analysis generally carried out: all things being equal, the stronger the proportion of tertiary employment (TER) is, the higher the multiplier will be, and conversely compared to the proportion of primary employment (PRI).

\section{IMPLEMENTATION OF THE RESEARCH}

\subsection{Mistakes to avoid}

Too often, economic impact studies on major sporting events considerably overevaluate the results, owing to calculation errors because of an insufficiently rigorous methodology (Preuss, 2006). We tried to avoid the following most common errors:

a) Failure to consider the substitution effect which concerns expenditure by local agents, and should therefore be excluded. If the 2007 RWC had not taken place, these local agents would have certainly engaged expenditure of another kind. Consequently, only expenditure by agents from outside the region is taken into consideration in determining the net injection for this study.

b) Failure to consider the time switching in consumption or investment. This concerns the decisions taken by the external agents before the 2007 RWC that were simply switched in time (brought forward or put back) to coincide with the period of the event. In that case, the corresponding rise in activity level cannot be attributed to the 2007 RWC. Our questionnaire was designed to identify the individuals who switched the time of their visit. Likewise, we were able to identify the occasional visitors who were present at the venue of the event not because of the 2007 RWC but for professional reasons, for instance. If they attend a match, only the additional sport-related expenditure must then be taken into account. 
Barget, Eric and Gouguet, Jean-Jacques. The importance of foreign spectators' expenditure in the tourism impact of mega-sporting events.

c) Omission of the crowding-out effects with regard to consumption or investment. Potential visitors may have been discouraged from coming to the region because they feared saturation of the territory or nuisances generated by the 2007 RWC. We defined a protocol for measuring such crowding-out effects by comparing the hotel statistics for September-October 2007 with those of the same period in 2006. The calculation was not, however, undertaken systematically in the host regions, as our in-depth interviews revealed that crowding-out effects were actually extremely low in this case, compared with other major worldwide sporting events.

d) Omission of leakages outside the territory (in consumption or investment), which is a source of over-estimation of the impact when the gross expenditure amount is taken instead of the value added, which accounts for leakages due to intermediate consumption or imported products.

The same applies to double counting (see figure 3) which can occur inside the tourism injection (a "giant screen" or "stadia" spectator, or an accompanying person can sometimes be the same person, the expenditure should only be considered once) and at the junction between the injection regarding organizational expenditure (the purchase of tickets is the major source of income of the organisation committee, and they should not be counted a second time in visitors expenditure).

\section{Figure 3. Synthesis of double counting to avoid during the calculation of economic} impact.

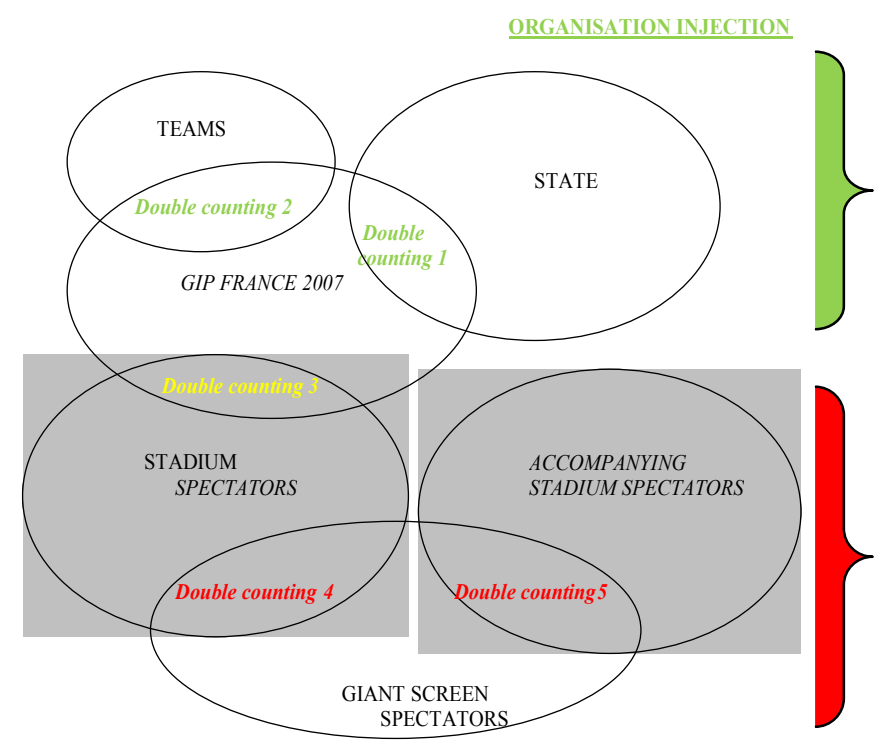

TOURISM INJECTION

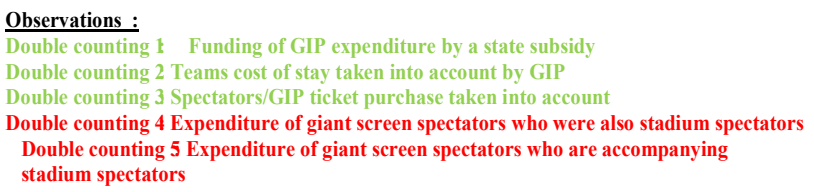

Source: authors.

The over-estimation of the multiplier is common, some use multipliers obtained in various studies and out of their territorial context. To avoid this bias, we preferred to use the same calculation for all regions to ensure homogeneity of results. On the 
Barget, Eric and Gouguet, Jean-Jacques. The importance of foreign spectators' expenditure in the tourism impact of mega-sporting events.

basis explained previously, the value of the multiplier varies between 2.02 (Languedoc-Roussillon) and 2.35 (lle de France). These results seem slightly higher than those of the ad hoc studies conducted (see for example Doucet, 2002). In any case, it appears that, beyond such relatively small differences, the calculation of net injections plays a key role, which involves the collection of reliable information in the field.

\subsection{Field survey}

The knock-on effects of a mega-sporting event on a territory come from three types of expenditure:

a) Consumption expenditure;

b) Expenditure relating to organization and management;

c) Investments expenditure.

The consumption expenditure derives from spending by "stadia" spectators, "giant screen" spectators, national teams and the people accompanying these different economic agents. Only consumers from outside the region are taken into consideration (the rest of France and foreigners). This is a means of approaching some of the territorial differences in the impact of the 2007 RWC, as the percentage of foreigners and spectators from outside the region varies from one case to another.

The expenditure in connection with organisation and management reflect the specificity of the organisation chart of the 2007 RWC. A public interest group (GIP) was created in Paris to supervise the general organisation of the 2007 RWC; a local coordination committee (LCC) was set up in each region to devise and implement the 2007 RWC promotion actions. But above all, the financing structure of the 2007 RWC is highly specific, featuring a leakage level that is proportionally higher than in competitions such as the Olympic Games or the Football World Cup. Among other things, the IRB, as owner of the 2007 RWC with head offices in Ireland, collects most of the commercial income from the event (sponsorship, TV broadcasting rights, VIP seats, executive boxes, a total $€ 130$ million in media broadcasting rights and $€ 60$ million in sponsoring). The economy of the GIP therefore relied almost exclusively on ticketing income.

The investment expenditure mainly concerns stadium construction and renovation. It is the State and the territorial communities that are concerned in the financing of such operations. But the investments in the case of the 2007 RWC remained extremely limited, as the event was organised in existing stadia that usually host football matches and have greater spectator capacities than those of the French rugby stadia.

Ultimately, it is a question of identifying among all the earlier flows those from outside the regional territory to calculate the injections, subtracting all capital outflows outside the territory and implementing the regional multiplier. The phase of data collection is crucial for the quality of the estimation. For this we administrated 5,500 questionnaires filled by face to face interviews with the spectators (stadia and giant screens) and accompanying persons. The spectator questionnaire is structured as follows: 
Barget, Eric and Gouguet, Jean-Jacques. The importance of foreign spectators' expenditure in the tourism impact of mega-sporting events.

a) A filter question was first asked on the age of the person interviewed, and the interview would not continue if the person was less than 15 years old. The choice to go down to the limit of 15 years old allows to take into account the fact that some young people came in groups and not with family; on that occasion, they made limited expenditures, personally. Ignoring this type of profiles of spectators would have led to overestimate the average expenditure of a spectator. However, the risk of lowering the age limit to include the sample is that the amount announced by the young people corresponds to pocket money, which is problematic when they came with their family (we would have liked in this case to have the expenditure of the entire family). However, we have not studied the repercussions of extending the limit to 18 years old, we nevertheless think that they would probably be minor, since for the site of Bordeaux for example, a group composed of 4,3 persons on average includes 0,4 young people under 18 years old.

b) Questions on the place of residence and travel conditions to go the stadium were asked (means of transport used, distance travelled, number of people in the vehicle, etc.). The place of residence is particularly important since, according to economic base theory, only economic agents from outside the territory of analysis (here the territory of the region hosting the Rugby World Cup) can be considered as a source of injection of money through their expenditures. Other data collected on the travel arrangements, were more oriented to calculate the use value as part of the costs-advantages of the Rugby World Cup.

c) A second block focused on the grounds and programming of the travel, it was designed to identify individuals for whom the Rugby World Cup was a determining factor of the decision to travel. Answers must be used to determine if expenditures incurred locally by an external spectator can really be considered as a consequence of the Rugby World Cup or whether they would have occurred without it. It is a question of excluding the expenditures of occasional visitors (who came for another reason and took the opportunity to attend the Rugby World Cup) and the expenditures just shifted in time rather than additional (if the trip was scheduled and was advanced or delayed to match the dates of the Rugby World Cup).

d) A part of the questionnaire on the composition of the group enabled to know the type of individuals accompanying the spectator. This is important as the expenditure asked subsequently covers all family members and we will move to the individual expenditure by simple division. It is also appropriate to identify the number of accompanying persons who do not enter the stadia, since their expenditures, which would not be spent without the Rugby World Cup, will also be taken into account (necessarily outside the stadium).

e) The part about the stay included a question on the number of the RWC matches seen, venue by venue. The aim is to know the number of matches seen in the region. It is then a matter of dividing the cost by the number of matches to get expenditure per match. Other questions concern the number of nights spent away from home and the type of accommodation used, which is used as a control variable of the accommodation expenditure announced.

f) The following passage was essential, since, on an item-by-item basis, a question was asked on the amount spent, by dissociating the part benefiting the host city, and the part benefiting the region (determining factor since the territory of analysis is the administrative region). The interviewers were instructed to spend more time on this sensitive question that involves several answers to write in the table (see 
Barget, Eric and Gouguet, Jean-Jacques. The importance of foreign spectators' expenditure in the tourism impact of mega-sporting events.

box 1). The expenditure of local spectators had no interest in the impact calculation, but useful comparisons could be made with the structure of expenditure of spectators from outside the region (visitors) who generate economic benefits.

g) The next part dealt with the personal characteristics of the spectator, with very traditional socio-economic information (age, gender, qualification, family situation, etc...) and information more specific to sport (sports license, number of sporting spectacles seen, etc) or to rugby (license, number of rugby matches attended, etc). This information is useful to better identify the profile of the audience, and comprehend the variables that affect expenditures. More directly related to the calculation of the economic impact, the monthly income bracket announced for the entire household helped refine the expenditure by category of household (earning more or less than €4 000 per month).

Box 1. Question 14 of the questionnaire.

How much money have you spent for you and your family for the different items? Indicate for each of them the approximate percentage spent in the city and in the region.

$$
\text { Amount \% in the city \% in the region }
$$

q14a: Transports :

q14b: Accommodation :

q14c: Expenditures in the stadium :

(Excepting tickets)

q14d: Food outside the stadium :

(Restaurant, food)

q14e: Outings/Entertainment :

(Cafés, cinema, nightclubs...)

q14f: Tourism :

q14q: Miscellaneous services:

(Laundry, hairdresser, doctor...)

q14h: Other expenditure outside the stadium:

(Newspapers, clothing, souvenirs...)

q14i : Overall expenditure

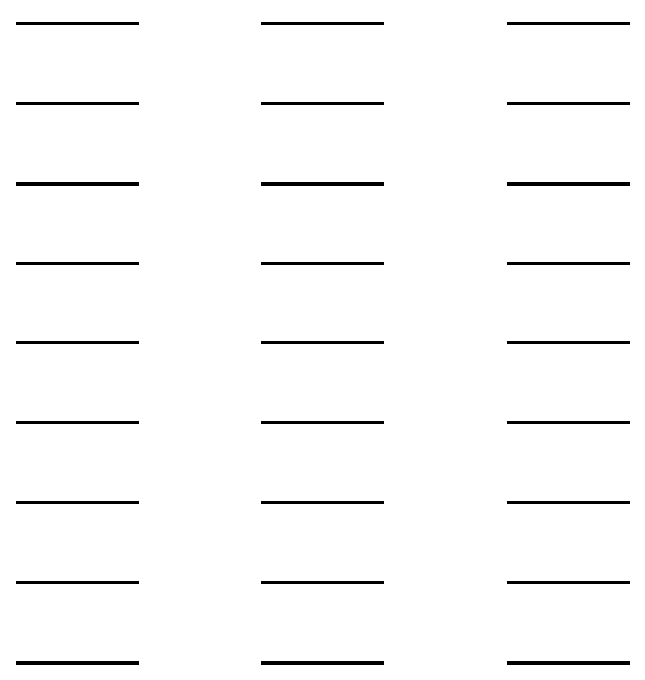

Source: authors.

The interview ended, after identifying the categories of tickets owned, and the conditions of the interview (interviewer, date, etc...), by an assessment of the quality of answers collected by the interviewer.

Based on the answers given by spectators, it was possible to calculate the average individual expenditure for a match and then move to the net injection using the following formula:

\section{IN] netteSPECTi $=$ DMOYI $\times($ NBSPECTI-NBTRANSI-NBOCCASI $) \times$ T $\times$ VAi}

INJ nette SPECTi is the net injection of spectators in the region $i, D M O Y i$ is the average individual expenditure for a match in the region $i, N B S P E C T i$ is the number of spectators of the matches organised in the region, NBTRANSi the number of 
Barget, Eric and Gouguet, Jean-Jacques. The importance of foreign spectators' expenditure in the tourism impact of mega-sporting events.

spectators who are time switchers, NBOCCASi the number of casuals, i.e. those who are in the region for an other purpose than the Rugby World Cup, and TxVAi the rate of regional value added.

As indicated in the previous formula, we nevertheless need to deduct two types of expenditure of the net injection obtained: the one of casuals present in the territory for another reason, and those of time switchers, i.e. who switched the time of their visit to make it coincide with the dates of the event. Casuals have been identified with a question on the main reason for the visit, and time switching information needed to be filled in another question. In both cases, these expenditures cannot be considered as injections, unless it is possible to isolate the amount spent specifically during the matches of the Rugby World Cup, which is very difficult to achieve in practise (Preuss, 2006). The proportion of casuals or time switchers could be estimated to $5 \%$ in Ile-de-France, $6 \%$ in Pays de la Loire and Rhône-Alpes, $7 \%$ in Midi-Pyrénées, $9 \%$ in Aquitaine, Nord-Pas de Calais and Provence-Alpes-Côte d'Azur, $16 \%$ in Languedoc-Roussillon.

In accordance with the base theory, the net injection only comes from French spectators from outside the region and foreign fans, the expenditure of people living in the region is only given for comparison. Foreigners account for $78 \%$ of the injection compared to $22 \%$ for French outside the region studied.

\section{MAIN RESULTS}

Two main results emerge from the analysis, on the one hand, globally, the expenditure of foreign tourists provides an understanding for the regional differences in the extent of the total impact of the Rugby World Cup. On the other hand, the nationality of tourists is a key explanatory variable of the extent of expenditure.

\subsection{The overall weight of foreign spectators}

\subsubsection{Domination of the tourism impact}

For all of the eight host regions, the structure of the impact shows a strong domination of the tourism impact, compared to the organisational impact. Visitors expenditure ("stadia" and "giant screen" spectators, accompanying persons), generate $70,3 \%$ of the total economic impact of the Rugby World Cup, and organisational expenditure, $29,7 \%$.

We observe (see figure 4) that the impact accounts for nearly two third $(63,5 \%)$ of the expenditure made by the spectators who entered the stadium while expenditure made by the organisation committee generate just under a quarter $(24,5 \%)$ of the overall impact. The impact structure of the Rugby World Cup is therefore easy to analyse, with a polarization on two types of expenditures, and in fact mainly on one. The low economic impact linked to the involvement of the State is explained by the limited investments in infrastructure that have been made. The Rugby World Cup appears as an event with a high tourist attractiveness, and very little as a planning tool for host territories. This feature clearly distinguishes it from the Olympic Games and the Football World Cup that give rise to big constructions. 
Barget, Eric and Gouguet, Jean-Jacques. The importance of foreign spectators' expenditure in the tourism impact of mega-sporting events.

Figure 4. Detailed impact structure on the eight regions.

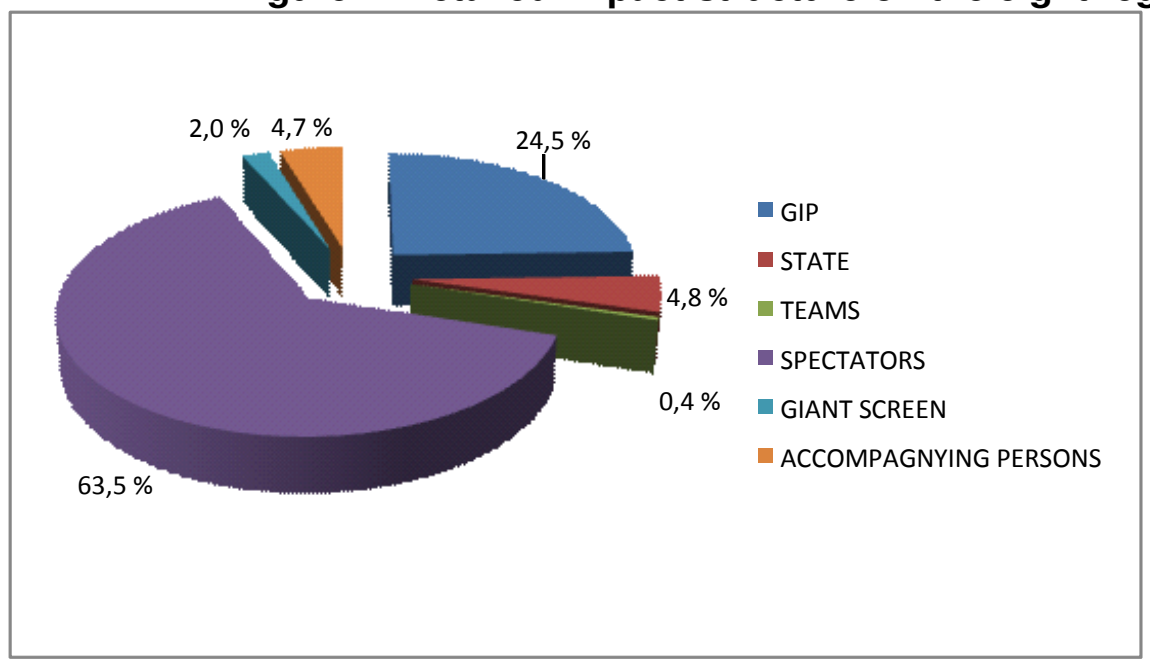

Source: authors.

The table 1 below, details the internal structure of the tourism impact, it shows some homogeneity between regions, with a strong dominance of spectators expenditure. Indeed, in general, the weight of expenditure made by "giant screen" spectators and accompanying persons is very low. This means that the Rugby world Cup in France did introduced the innovation of giant screens as a new form of consumption of sporting events ( 885,800 fans in total), but this phenomenon has not reached yet the extent that it knows in other sports and in other countries, such as football in Britain. In that country some fans, who for lack of seats in the stadium or lack of financial means to enter it, decide to come on site to follow the competition while enjoying the live atmosphere. In addition they have the possibility to consume products that are forbidden inside the stadia.

Table 1. Nature of the tourism impact.

\begin{tabular}{|l|l|l|l|l|}
\cline { 2 - 5 } \multicolumn{1}{c|}{} & $\begin{array}{l}\text { STADIUM } \\
\text { SPECTATORS } \\
\text { IMPACT }\end{array}$ & $\begin{array}{l}\text { GIANT SCREEN } \\
\text { SPECTATORS } \\
\text { IMPACT }\end{array}$ & $\begin{array}{l}\text { ACCOMPANYING } \\
\text { PERSONS IMPACT }\end{array}$ & $\begin{array}{l}\text { TOTAL TOURISM } \\
\text { IMPACT }\end{array}$ \\
\hline Aquitaine & $97,5 \%$ & $1,5 \%$ & $1,0 \%$ & $100,0 \%$ \\
\hline Île-de- France & $93,8 \%$ & $0,6 \%$ & $5,6 \%$ & $100,0 \%$ \\
\hline $\begin{array}{l}\text { Languedoc- } \\
\text { Roussillon }\end{array}$ & $88,5 \%$ & $2,4 \%$ & $9,1 \%$ & $100,0 \%$ \\
\hline Midi-Pyrénées & $68,5 \%$ & $22,1 \%$ & $9,4 \%$ & $100,0 \%$ \\
\hline $\begin{array}{l}\text { Nord-Pas de } \\
\text { Calais }\end{array}$ & $91,5 \%$ & $0,0 \%$ & $8,5 \%$ & $100,0 \%$ \\
\hline Pays de la Loire & $85,6 \%$ & $1,9 \%$ & $12,4 \%$ & $100,0 \%$ \\
\hline $\begin{array}{l}\text { Provence-Alpes- } \\
\text { Côte d'Azur }\end{array}$ & $88,6 \%$ & $4,8 \%$ & $6,6 \%$ & $100,0 \%$ \\
\hline Rhône-Alpes & $90,3 \%$ & $0,4 \%$ & $9,3 \%$ & $100,0 \%$ \\
\hline
\end{tabular}

Source: authors. 
Barget, Eric and Gouguet, Jean-Jacques. The importance of foreign spectators' expenditure in the tourism impact of mega-sporting events.

\subsubsection{Importance of foreign spectators}

Going further in the analysis, we notice that the injection made by "stadia" spectators is mainly due to foreigners, as shown in table 2.

In Aquitaine, if foreigners represent $58.1 \%$ of spectators from outside the region, they were at the origin of $90.9 \%$ of the net injection of "stadia" spectators. This is due to a much higher average consumption basket of foreigners compared to the French one. Such a gap between spectator mass and extent of expenditure in all regions reaches its peak in Midi-Pyrénées: foreigners account only for $26,8 \%$ of the spectators concerned but their injection represents $71,1 \%$ of the total expenditure. The case of this region shows even more that the extent of the net injection of "stadia" spectators comes largely from the weight of foreigners belonging to the highest income category, i.e. more than $€ 4,000$ of average income in our sample (see tableau 3 ).

Table 2. Share of foreigners in the "stadia" spectators injection

\begin{tabular}{|l|c|c|}
\hline Regions & $\begin{array}{c}\text { Share of foreigners in "stadia" } \\
\text { spectators injection }\end{array}$ & $\begin{array}{c}\text { Share of foreigners in } \\
\text { spectators from outside the } \\
\text { region }\end{array}$ \\
\hline Aquitaine & $90,9 \%$ & $58,1 \%$ \\
\hline Île-de-France & $71,5 \%$ & $40,5 \%$ \\
\hline Languedoc-Roussillon & $80,0 \%$ & $52,6 \%$ \\
\hline Midi-Pyrénées & $71,1 \%$ & $26,8 \%$ \\
\hline Nord-Pas de Calais & $89,7 \%$ & $58,3 \%$ \\
\hline Pays de Loire & $89,3 \%$ & $57,4 \%$ \\
\hline Provence-Alpes-Côte d'Azur & $79,2 \%$ & $42,3 \%$ \\
\hline Rhône-Alpes & $65,9 \%$ & $44,9 \%$ \\
\hline
\end{tabular}

Source: authors.

Table 3. Net injection by category of spectators in Midi-Pyrenees.

\begin{tabular}{|l|l|l|l|l|l|}
\hline $\begin{array}{l}\text { Spectators from } \\
\text { outside the region }\end{array}$ & $\begin{array}{l}\text { Number of } \\
\text { spectators }\end{array}$ & $\%$ of spectators & $\begin{array}{l}\text { Expenditure } \\
\text { basket (€) }\end{array}$ & Injection amount (€) & \% of injection \\
\hline $\begin{array}{l}\text { Income below } \\
€ 4,000 / \text { month } \\
\text { Income above } \\
€ 4,000 / \text { month }\end{array}$ & 27,257 & 66,1 & 44,9 & 738,014 & 51,3 \\
\hline Total & 41,225 & 100,0 & 83,1 & 699,145 & 48,7 \\
\hline Foreigners & $\begin{array}{l}\text { Number of } \\
\text { spectators }\end{array}$ & $\%$ of spectators & $\begin{array}{l}\text { Expenditure } \\
\text { basket }(\boldsymbol{€})\end{array}$ & Injection amount (€) & $\%$ of injection \\
\hline $\begin{array}{l}\text { Income below } \\
\text { In,000/month } \\
\text { Income above }\end{array}$ & 7,030 & 46,3 & 194,7 & 824,392 & 22,3 \\
\hline All foreigners & 8,121 & 53,7 & 553,6 & $2,708,233$ & 77,7 \\
\hline
\end{tabular}

Source: authors.

With an average basket of $€ 553.63$ (compared to the $€ 44.95$ of the lower income bracket of French spectators from outside the region), the spectators with the higher income are at the origin of $77.7 \%$ of the foreigners net injection. The income plays a 
Barget, Eric and Gouguet, Jean-Jacques. The importance of foreign spectators' expenditure in the tourism impact of mega-sporting events.

key role in the amount spent as shown in the comparisons we have established between spectators having more or less than $€ 4,000$ monthly income for the household. To illustrate this, in Provence-Alpes-Cote d'Azur, a wealthy foreigner spends on average $€ 2,021$ for the family, while consumption is reduced to $€ 1,147$ if he has fewer resources. Similar disparities are found in other host regions (from $€ 682$ to $€ 433$ in Midi-Pyrenées, and from €906 to €520 in Languedoc-Roussillon). We are therefore well aware of the importance of the attractiveness of the matches or of the territory for foreigners with a high purchasing power.

\subsubsection{Two types of effect}

The table 4 shows that the extent of the impact of the Rugby World Cup in each region depends on two variables:

- The number of tickets sold, called the size effect.

- The distribution of tickets among nationals and foreigners, called the structure effect.

Table 4. Factors explaining the regional disparities of impact.

\begin{tabular}{|c|c|c|c|c|c|c|c|c|}
\hline $\begin{array}{l}\text { HOST } \\
\text { REGIONS }\end{array}$ & $\begin{array}{l}\text { TOTAL } \\
\text { IMPACT }\end{array}$ & $\begin{array}{l}\text { TOURISM } \\
\text { IMPACT }\end{array}$ & $\begin{array}{l}\text { \% TOURISM } \\
\text { IMPACT } \\
\end{array}$ & $\begin{array}{l}\text { NUMBER OF } \\
\text { MATCHES }\end{array}$ & $\begin{array}{l}\text { NUMBER } \\
\text { OF TICKETS }\end{array}$ & $\begin{array}{l}\% \text { LOCAL } \\
\text { TICKETS }\end{array}$ & $\begin{array}{l}\text { \% FOREIGN } \\
\text { TICKETS }\end{array}$ & $\begin{array}{l}\text { \%TRI NATION } \\
\text { TICKETS }\end{array}$ \\
\hline Aquitaine & 38953987 & $32391662]$ & $83,2 \%$ & 4 & 133292 & $51,2 \%$ & $28,4 \%$ & $28,01 \%$ \\
\hline |̂̂le-de- France & 253791824 & 135490664 & $53,4 \%$ & 12 & 771104 & $46,0 \%$ & $21,9 \%$ & $16,54 \%$ \\
\hline Languedoc-Roussillon & 30840970 & 23035417 & $74,7 \%$ & 4 & 111607 & $46,6 \%$ & $28,1 \%$ & $52,77 \%$ \\
\hline Midi-Pyrénées & 20733089 & 14659424 & $70,7 \%$ & 4 & 138690 & $59,4 \%$ & $10,9 \%$ & $42,65 \%$ \\
\hline Nord-Pas de Calais & 32157761 & $24456850^{\prime}$ & $76,1 \%$ & 3 & 107786 & $56,3 \%$ & $35,7 \%$ & $9,63 \%$ \\
\hline Pays de la Loire & 27387742 & $21792820^{\prime}$ & $79,6 \%$ & 3 & 109156 & $45,3 \%$ & $31,4 \%$ & $1,76 \%$ \\
\hline Provence-Alpes-Côte d'Azur & 145350165 & 135083035 & $92,9 \%$ & 6 & $324377^{\prime}$ & $38,1 \%$ & $26,2 \%$ & $19,55 \%$ \\
\hline Rhône-Alpes & 40506456 & $27517425^{\prime}$ & $67,9 \%$ & 6 & 230300 & $55,3 \%$ & $20,1 \%$ & $39,15 \%$ \\
\hline AGGREGATION & 589721995 & 414427298 & $70,3 \%$ & 42 & $1926312^{7}$ & $47,9 \%$ & $23,4 \%$ & $23,30 \%$ \\
\hline
\end{tabular}

Source: authors.

If we take the ranking of regions in decreasing order of impact, it is possible to synthesize these two effects (see table 5).

Table 5. Synthesis of the key elements of the extent of the economic impact.

\begin{tabular}{|c|c|c|}
\hline HOST REGIONS & EFFECT SIZE & STRUCTURE EFFECT \\
\hline Île-de-France & +++ & $=$ \\
\hline Provence-Alpes-Côte d'Azur & ++ & ++ \\
\hline Rhône-Alpes & + & - \\
\hline Aquitaine & - & + \\
\hline Nord-Pas de Calais & - & + \\
\hline Languedoc-Roussillon & - & + \\
\hline Pays de Loire & - & $=$ \\
\hline Midi-Pyrénées & - & --- \\
\hline
\end{tabular}

Source: authors.

The case of lle-de-France, the first by far in terms of economic impact, is very particular, because of the impressive number of tickets sold compared to the other regions, and also because the impact of organization expenditure was almost as important as tourism expenditure (these represent $53 \%$ of the total impact). It should 
Barget, Eric and Gouguet, Jean-Jacques. The importance of foreign spectators' expenditure in the tourism impact of mega-sporting events.

not be forgotten that the organization of the event was highly centralized and that the organization committee, the Public Interest Group France 2007, was located in Paris. The distribution of spectators depending on their origin is close to the average of the eight regions, therefore it is not a structure effect that is decisive here but a size effect $(771,104$ tickets sold).

The impact recorded by Provence-Alpes-Cote d'Azur (PACA) is a result of tourism expenditures at $92.9 \%$. This impact can be explained both by a size effect $(324,377$ spectators) and a structure effect, the proportion of local spectators being low (38.1\% for $47.9 \%$ on all the host regions). The proportion of foreigners is slightly above the average (especially the spectators from outside Europe, nationals from the Pacific represent over a quarter of foreigners).

The impact on Rhone-Alpes may seem disappointing considering the number of tickets available (230, 300 spectators) on two sites (Saint-Etienne and Lyon). It can be explained by a high proportion of local spectators (55.3\%). However, the part below the average of the eight regions regarding foreign spectators was offset by the fact that they are non-Europeans for more than a half (who have higher level of expenditure).

Aquitaine enjoys nearly the same economic benefits than Rhone-Alpes despite a number of tickets $(133,292)$ being almost two times lower. This reflects a greater representation of foreign spectators in the audience. The same remarks can be made for Nord-Pas de Calais and Languedoc-Roussillon.

The lowest impacts recorded are in Pays de la Loire and in Midi-Pyrénées, these regions have cumulated a negative size effect $(109,156$ tickets for the first one, and 138,690 for the second one), and an unfavourable structure effect. For Pays de la Loire the almost non-representation of non-Europeans spectators explains the weak impact. In Midi-Pyrénées, the strong presence of local spectators not creating any value-added (59.4\%), associated with a low proportion of foreign tourists $(10.9 \%)$, explains the fact that the economic activity has not reached the level expected.

\subsection{The nationality, key explanatory variable}

\subsubsection{Analysis of expenditure baskets}

The nationality of the spectators is a key explanatory variable of the amount and structure of expenditures (see table 6). We have reached this conclusion without taking into account the exchange rates differentials. Yet, we know that to make international comparisons, we can use a method of calculation based on the purchasing power parity (PPP). This requires establishing a standardized basket of goods and services which can be a problem. By eliminating the exchange rates, the validity of the comparison then depends on the quality of the definition of the basket. This gives an idea of the great difficulty of international comparisons with respect to the standard of living. For this reason we did not get beyond the analysis of expenditure baskets, provided that the extent and the nature of such expenditures is more conditioned, in our case very specific to rugby fans, by their culture than their purchasing power. 
Barget, Eric and Gouguet, Jean-Jacques. The importance of foreign spectators' expenditure in the tourism impact of mega-sporting events.

Table 6. Amount and structure of expenditures by nationality.

\begin{tabular}{|c|c|c|c|c|c|c|c|c|c|c|}
\hline \multirow[t]{2}{*}{ COUNTRY GROUPS } & \multirow{2}{*}{$\begin{array}{c}\text { AVERAGE } \\
\text { EXPENDITURE }(€)\end{array}$} & \multirow{2}{*}{$\begin{array}{c}\% \\
\text { TRANSPORT }\end{array}$} & \multirow{2}{*}{$\begin{array}{c}\text { EXPENDITURE EXCLUDING } \\
\text { TRANSPORT }\end{array}$} & \multicolumn{7}{|c|}{ \% OF EXPENDITURE EXCLUDING TRANSPORT COMPOSED OF... } \\
\hline & & & & ACCOMODATION & SHOPPING IN STADIUM & FOOD & OUTING & TOURISM & SERVICES & OTHER \\
\hline Africa & 2596 & 33,4 & 1728 & 42,3 & 7,0 & 26,9 & 12,9 & 3,4 & 0,4 & 7,1 \\
\hline North America & 2301 & 34,3 & 1511 & 36,3 & 11,6 & 23,8 & 9,1 & 6,4 & 1,1 & 11,6 \\
\hline Australia & 4488 & 30,3 & 3127 & 39,2 & 7,0 & 27,2 & 13,0 & 4,6 & 1,0 & 8,0 \\
\hline Other $(A S, A)$ & 3341 & 40,6 & 1986 & 36,2 & 10,6 & 19,5 & 11,3 & 11,4 & 0,5 & 10,6 \\
\hline British isles & 1274 & 33,7 & 845 & 36,0 & 11,1 & 24,7 & 17,1 & 3,4 & 0,6 & 7,0 \\
\hline Rest of Europe & 644 & 29,8 & 452 & 24,5 & 11,2 & 31,1 & 15,3 & 4,3 & 0,6 & 13,0 \\
\hline French outside the region & 401 & 40,9 & 237 & 12,5 & 17,3 & 26,8 & 8,9 & 27,3 & 0,4 & 6,7 \\
\hline French from the region & 75 & 42,4 & 43 & 2,4 & 45,0 & 27,7 & 8,0 & 9,4 & 0,2 & 7,4 \\
\hline Pacific & 4127 & 41,8 & 2402 & 48,7 & 10,7 & 18,3 & 9,8 & 3,5 & 0,9 & 8,0 \\
\hline Grand total & 633 & 40,0 & 380 & 15,1 & 27,3 & 26,8 & 10,3 & 12,7 & 0,4 & 7,5 \\
\hline
\end{tabular}

Source: authors.

The highest expenditures are made by fans from the Pacific area with Australia $(€ 4,488$ on average), or New-Zealand and the other Pacific islands $(€ 4,127)$. The nationals of other distant continents also have a high amount of expenditure: Asia and South America (Argentina) with $€ 3,341$; Africa with $€ 2,596$ (mainly South Africa); North America with $€ 2,301$. It therefore appears that Europeans expenditure is significantly lower. British nationals are the highest spenders with $€ 1,274$, representing almost twice the level of expenditure of other Europeans with $€ 644$. In this context, France stands out as a low spender with $€ 401$ for French people from outside the host region and only $€ 75$ for local spectators.

Table 7. Average expenditure by country groups.

\begin{tabular}{|l|c|c|c|}
\hline COUNTRY GROUPS & $\begin{array}{c}\text { AVERAGE EXPENDITURE } \\
\text { EXCLUDING TRANSPORT (E) }\end{array}$ & $\begin{array}{c}\text { AVERAGE NUMBER } \\
\text { OF MATCHES SEEN }\end{array}$ & $\begin{array}{c}\text { AVERAGE EXPENDITURE } \\
\text { PER MATCH }\end{array}$ \\
\hline Africa & 1728,4 & 2,7 & 643 \\
\hline North America & 1510,6 & 2,2 & 690 \\
Australia & 3127,4 & 3,1 & 1009 \\
Other (AS, A) & 1986,3 & 2,4 & 834 \\
British isles & 844,7 & 2,5 & 339 \\
Rest of Europe & 452,3 & 1,8 & 257 \\
French outside the region & 237,1 & 2,3 & 103 \\
French from the region & 42,9 & 2,2 & 19 \\
Pacific & 2402,5 & 2,9 & 834 \\
\hline Grand total & 379,9 & 2,3 & 165 \\
\hline
\end{tabular}

Source: authors.

Beyond the overall expenditure, when analyzing the expenditure basket by matches, excluding transport expenditure, the differences between nationalities remain but with Papeles de Europa 
Barget, Eric and Gouguet, Jean-Jacques. The importance of foreign spectators' expenditure in the tourism impact of mega-sporting events.

slight differences (see table 7). Australians are by far the biggest spenders among nationals of the most distant countries. A British spectator spends the third of an Australian spectator and spends almost 25\% more than a spectator from the rest of Europe. As for the average expenditure of French people, it could lead to wonder about the extent of sporting culture in our country.

If the absolute amount of the expenditure gives some interesting comparative elements between nationalities, it should be noted however that there is a relative homogeneity, with few exceptions, in the structure of the spectators' total expenditure by major items, regardless of nationality. Transport expenditure weigh between 30 and $42 \%$ of total expenditure, and expenditures excluding transport are divided between accommodation, food, outings with some specificities according to nationalities:

- French people living in the host regions have a much higher level of expenditure in stadia than the overall average (45\% against $27.3 \%)$. However, the amounts on which rely these percentages must not be forgotten. The low level of the French individual expenditure ( $43 €$ ) makes that an Australian spectator, with only $7 \%$ of its total expenditure, inject ten times more money in a stadia than a French national;

- French people from outside the region spend more than three quarters of their budget, excluding transport, on tourism $(27.3 \%)$, which make them different from the rest of the spectators (with an average of $12.7 \%$ );

- Regarding outings, supporters from the British Isles and the rest of Europe differ significantly from the national average of $10.3 \%$ with respectively $17.1 \%$ and $15,3 \%$;

- Nationals of the most distant countries differ from the other nationalities with accommodation expenditure well above the average (15.1\%), which is logical. The highest percentage is made by Pacific Island nationals who spend almost half of their budget on accommodation.

We notice that the amounts spent are highly heterogeneous according to nationalities. Insofar as foreign supporters are concentrated in cities where their national team will play, as shown in table 8 , the successful regions are the ones that have been granted matches involving teams of the Southern Hemisphere (lle-deFrance and Rhône-Alpes heading the list). In terms of prospective, these results mean that the nationality of the spectators could be an important adjustment variable in the regional distribution of the impact of the Rugby World Cup since it would be sufficient to attract the nationalities that spend the most.

Nevertheless, sports programming is exogenous to the host regions and has different criteria. It would be interesting to discuss at the organizational level of major sporting events if non-sporting factors may count in the attribution of matches.

\subsubsection{Analysis of socio-demographic profiles}

To understand the results on the injection of foreign spectators and their consumption basket, knowledge of their socio-demographic profiles is necessary. Indeed, it appears that the expenditure behaviour of different nationalities vary widely depending on variables which characterize cultural values. As a result, it is not so much the geographical origin of the spectators that matters but their national or Papeles de Europa

25 (2012): 27-50

Doi: http://dx.doi.org/10.5209/rev_PADE.2012.n25.41094 
Barget, Eric and Gouguet, Jean-Jacques. The importance of foreign spectators' expenditure in the tourism impact of mega-sporting events.

continental culture. To do so, we will group the foreign spectators in three categories ranked in descending order of the amount of their expenditure: Nationals from outside Europe; Europeans; and French people.

Table 8. Distribution of spectators by nationality and venue.

\begin{tabular}{|c|c|c|c|c|c|c|c|c|c|c|c|c|c|}
\hline \multirow{2}{*}{$\begin{array}{l}\text { Sum of sales } \\
\text { Countries }\end{array}$} & \multicolumn{13}{|c|}{ Competition venue } \\
\hline & Bordeaux & Lens & Lyon & Marseille & Montpellier & Nantes & Paris & Saint-Denis & Saint Étienne & Toulouse & Total 1 & Tour operators & Total 2 \\
\hline UNITED KINGDOM & 8075 & 17690 & 5226 & 28299 & 6444 & 24683 & 33500 & 43488 & 4920 & 4175 & 176500 & 41567 & 218067 \\
\hline AUSTRALIA & 2583 & 144 & 2316 & 3148 & 3125 & 104 & 474 & 1549 & 485 & 337 & 14265 & 39727 & 53992 \\
\hline NEW- ZEALAND & 40 & 24 & 702 & 1258 & 132 & 7 & 97 & 1286 & 66 & 659 & 4271 & 26496 & 30767 \\
\hline IRLAND & 8702 & 186 & 235 & 913 & 349 & 184 & 7143 & 5403 & 125 & 227 & 23467 & 5063 & 28530 \\
\hline SOUTH AFRICA & 3 & 350 & 6 & 556 & 424 & 6 & 489 & 802 & 10 & 10 & 2656 & 14378 & 17034 \\
\hline UNITED STATES & 649 & 381 & 381 & 1183 & 967 & 164 & 918 & 1502 & 467 & 150 & 6762 & 9490 & 16252 \\
\hline ITALY & 57 & 33 & 229 & 6944 & 153 & 22 & 386 & 571 & 3142 & 46 & 11583 & & 11583 \\
\hline SPAIN & 586 & 95 & 340 & 2306 & 898 & 150 & 371 & 931 & 346 & 519 & 6542 & & 6542 \\
\hline BELGIUM & 116 & 2527 & 170 & 530 & 211 & 34 & 916 & 1223 & 105 & 66 & 5898 & & 5898 \\
\hline SWITZERLAND & 159 & 79 & 1371 & 940 & 274 & 39 & 412 & 1074 & 602 & 121 & 5071 & & 5071 \\
\hline GERMANY & 186 & 505 & 483 & 928 & 428 & 79 & 515 & 711 & 226 & 214 & 4275 & & 4275 \\
\hline JAPAN & 192 & 38 & 189 & 119 & 47 & 4 & 154 & 273 & 19 & 156 & 1191 & 2997 & 4188 \\
\hline ARGENTINA & 3 & & 125 & 418 & 29 & 2 & 164 & 611 & 9 & 1 & 1362 & 2328 & 3690 \\
\hline THE NETHERLANDS & 140 & 940 & 89 & 528 & 168 & 61 & 477 & 633 & 146 & 87 & 3269 & & 3269 \\
\hline CANADA & 622 & 80 & 90 & 363 & 134 & 56 & 179 & 352 & 76 & 45 & 1997 & 719 & 2716 \\
\hline HONG -KONG & 46 & 27 & 26 & 133 & 48 & 8 & 85 & 161 & 43 & 28 & 605 & 1200 & 1805 \\
\hline PORTUGAL & 35 & 10 & 359 & 149 & 112 & 2 & 141 & 85 & 280 & 222 & 1395 & & 1395 \\
\hline LUXEMBOURG & 78 & 60 & 70 & 178 & 51 & 21 & 230 & 412 & 54 & 33 & 1187 & & 1187 \\
\hline OTHERS & 352 & 215 & 621 & 1635 & 435 & 178 & 615 & 1842 & 240 & 378 & 6511 & 0 & 6511 \\
\hline Total foreigners by site & 22624 & 23384 & 13028 & 50528 & 14429 & 25804 & 47266 & 62909 & 11361 & 7474 & 278807 & 143965 & 422772 \\
\hline
\end{tabular}

Source: authors.

Table 9. The socioeconomic profile of spectators of the Rugby World Cup.

\begin{tabular}{|c|c|c|c|c|c|c|c|c|c|c|}
\hline CONIRYGROPS & Africa & NorthAmerica & Australia & Other $(A S, A)$ & Britishisles & Rest of Europe & Frenchoutside the region & nnchfromthered & Padic & Total \\
\hline \multicolumn{11}{|l|}{ COUNIRYGROUPS } \\
\hline$\%$ Men & 76,6 & 74,5 & 74,6 & 82,0 & 77,3 & 78,3 & 80,0 & 78,7 & 73,3 & 78,6 \\
\hline \%Narriedor cohabiting & 70,1 & 63,6 & 6,1 & 60,0 & 62,4 & 62,6 & 70,4 & 6,8 & 68,2 & 6,7 \\
\hline \%Hgher education & 25,7 & 16,7 & 30,8 & 5,1 & 32,1 & 35,5 & 53,6 & 50,7 & 45,5 & 47,7 \\
\hline Average income & 5232 & 4943 & 5369 & 4506 & 4805 & 3195 & 2027 & 1825 & 4622 & 2455 \\
\hline Average age & 39 & 38 & 43 & 36 & 40 & 36 & 39 & 39 & 43 & 39 \\
\hline \multicolumn{11}{|l|}{ SPORIING PROFLE } \\
\hline Nb of sporting spectades & 12,3 & 11,6 & 11,7 & 12,1 & 9,2 & 8,8 & 7,5 & 7,8 & 14,3 & 8,5 \\
\hline Nb of rugby spectades & 8,6 & 5,0 & 8,0 & 4,6 & 6,2 & 5,2 & 4,6 & 3,8 & 11,2 & 4,8 \\
\hline \% of people practising rugby & 18,1 & 35,2 & 20,7 & 36,2 & 21,0 & 29,7 & 19,8 & 16,4 & 32,6 & 19,2 \\
\hline \%of people practising a sport & 72,4 & 81,1 & 64,5 & 55,1 & 65,0 & 61,8 & 61,7 & 63,9 & 64,4 & 63,6 \\
\hline \multicolumn{11}{|l|}{ TYPEOFGROP } \\
\hline \%camewithfamily & 51,4 & 62,0 & 56,3 & 48,8 & 49,1 & 42,9 & 60,7 & 55,8 & 65,0 & 55,9 \\
\hline Average number fanilymembers & 1,2 & 1,6 & 1,3 & 1,2 & 1,1 & 1,5 & 1,2 & 1,3 & 1,5 & 1,3 \\
\hline Averagenb. accompanying persons & 7,2 & 7,3 & 7,8 & 5,9 & 3,9 & 3,4 & 3,6 & 3,6 & 5,0 & 3,9 \\
\hline Average number of young people & 1,5 & 0,4 & 0,9 & 0,3 & 0,2 & 0,3 & 0,3 & 0,9 & 0,3 & 0,6 \\
\hline \multicolumn{11}{|l|}{ ACCONDDATION } \\
\hline Average number of nights & 9,2 & 11,9 & 17,8 & 5,2 & 7,2 & 4,0 & 0,7 & - & 16,1 & 4,0 \\
\hline \%stayinginahotel & 86,0 & 71,1 & 83,9 & 82,9 & 80,3 & 63,4 & 50,4 & - & 78,9 & 6,1 \\
\hline Average expenditure for accomodation $(€)$ & 875,3 & 818,8 & 1402,0 & 935,6 & 436,5 & 179,6 & 109,2 & - & 1360,0 & 235,7 \\
\hline \multicolumn{11}{|l|}{ TORSM } \\
\hline 1stvisit toFrance & 48,9 & 56,3 & 45,5 & 48,7 & 13,5 & 16,2 & - & - & 48,4 & 27,9 \\
\hline \%thinking of coming again & 80,0 & 53,3 & 60,0 & 63,2 & 94,0 & 97,3 & - & - & 83,9 & 85,0 \\
\hline
\end{tabular}

Source: authors. 
Barget, Eric and Gouguet, Jean-Jacques. The importance of foreign spectators' expenditure in the tourism impact of mega-sporting events.

\section{Nationals from outside Europe}

In terms of expenditure basket, the ranking for non-European nationals is as follows: 1) Australians, 2) New Zealanders and Pacific Islands; 3) Asians and South Americans ("other"); 4) Africans; 5) North Americans. All these spectators have declared an average income above $€ 4,500$. Differentiations appear then at the level of the other variables, as shown in the following summary table (see table 9 ).

First, if we compare the supporters from the Pacific, it appears that there are fewer Australians with a higher education degree (30.8\%) than New Zealanders and nationals from the Pacific Islands (45.5\%), these percentages remain below the average for the general public (47.7\%). These two populations are older than the average (43 against 39) and are rugby fans or sportsmen in general. Australians attend eight rugby matches a year (against an overall average of 4.8); one third of New Zealanders practice rugby and they attend 11.2 rugby matches a year.

Asians and South Americans are distinguished primarily by a higher level of higher education graduates (57.1\%), a slightly higher percentage of men than the average and a higher percentage of rugby practitioners. South Africans have relatively less higher education graduates but are overrepresented compared to the average regarding the attendance at sporting events and the practice of sport.

Similarly, North Americans have a profile marked by sports practitioners but have the lowest percentage of higher education graduates of all $(16.7 \%$ against $47.7 \%$ on average).

\section{European nationals}

Two characteristics predominate for European citizens: spectators from the British Isles (the majority) have high incomes but a rate of higher education graduates below the sample average (32.1\% against $47.7 \%)$. Spectators from other European countries differ from British spectators by a significantly lower income (€ 3,195 against $€ 4,805$ ), they are younger (36 years on average, i.e. the youngest, for all nationalities) and their rate of practice of rugby is stronger with $29 \%$.

\section{French nationals}

The two categories of French spectators (whether or not living in the host region) have relatively similar profiles. They are fundamentally different from other nationalities by two characteristics: a much higher proportion of higher education graduates and much lower incomes. Insofar as the event takes place in France, there is a windfall effect, the event is affordable to people who may not have very high incomes although highly educated. Moreover, the sporting culture of spectators is not far from the average.

In summary, the most discriminative variables seem to be the income, the diploma and the sporting culture. This profile should nevertheless be combined with the number of foreign spectators to understand the extent of the regional impact of the Rugby World Cup. 
Barget, Eric and Gouguet, Jean-Jacques. The importance of foreign spectators' expenditure in the tourism impact of mega-sporting events.

\section{CONCLUSION}

The results show that the Rugby World Cup had a positive economic impact in all regions, but with considerable differences due mainly to the presence of "rich" foreign spectators. This strong relative share of the injection of foreign tourists is also due to the fact that the Rugby World Cup did not require the construction of new sport facilities. The impact of the Rugby World Cup in the regions has therefore largely been conditioned by attractive matches and the overall attractiveness of the territory for foreigners (Île-de-France or Provence-Alpes-Côte d'Azur for example).

In the end, regional disparities of impact can be explained both by a size effect (number of tickets sold) and by a structure effect (relative shares of different nationalities). Among the regions, these effects more or less reinforce or oppose one another. The ideal case is obviously the region that hosts a lot of matches and which top matches attract many foreigners with a high income and a high level of expenditure. Conversely, some regions that had few interesting matches could offset a part of this disadvantage thanks to the arrival of wealthy foreigners attracted by their national team. These results confirm those emphasized elsewhere (Ritchie \& Yangzhou, 1987).

The regional economic impact was therefore closely linked to the quality of the matches on the one hand and to the nationalities concerned on the other hand. This means it migh be possible to think of a real hosting policy for this kind of event to better distribute the total economic impact among different regions. Two variables can be modulated:

- The number of tickets (or matches) attributed to each region;

- And the type of match attributed as to its place in the tournament (qualifying matches or final round) but also as to the nationalities concerned.

It is therefore clear that the totality of the regional impact will not be completely controlled. If a part of the qualifying matches can be attributed at the beginning of the competition by the organizer, final round matches depend then on the sporting results and cannot be planned. From there, the host regions can make advance calculations to estimate their chances to optimize the economic benefits on their region. 
Barget, Eric and Gouguet, Jean-Jacques. The importance of foreign spectators' expenditure in the tourism impact of mega-sporting events.

\section{REFERENCES}

Baade, Robert (1996) «Professional sports as a catalyst for metropolitan economic development », Journal of urban affairs, vol. 18, $\mathrm{n}^{0}$ 1, p. 1-17.

Barget, Eric et Jean-Jacques Gouguet (2010a) Evénements sportifs: impact économique et social, coll. «Management et sport», Bruxelles: De Boeck. $462 \mathrm{p}$.

Barget, Eric et Jean-Jacques Gouguet (2010b) De l'évaluation des grands événements sportifs. La coupe du monde de rugby 2007 en France, Limoges : PULIM. 386 p.

Barget, Eric et Jean-Jacques Gouguet (2010c) «La mesure de l'impact économique des grands événements sportifs : l'exemple de la Coupe du monde de rugby 2007 », Revue d'Économie Régionale et Urbaine, n² 2, p. 379-408.

Barget, Eric et Jean-Jacques Gouguet (2010d) « Une analyse coûts-bénéfices de la Coupe du Monde de Rugby 2007 en France: Une perspective régionale », Économie appliquée, vol. 63, n³, p. 205-228

Blake, Adam (2005) «The economic impact of the London 2012 Olympics », Christel DeHann Tourism and Travel Research Institute. Non publié. Nottingham: Nottingham University Business School.

Bourg, Jean-François et Jean-Jacques Gouguet (1998) Analyse économique du sport, Paris : PUF. 380 p.

Chappelet, Jean-Loup (dir.) (2006) Les politiques publiques d'accueil d'événements sportifs, Paris : L'Harmattan, coll. «Questions contemporaines », 237 p.

Copeland, B. R. (1991) Tourism, Welfare and de-industrialisation in a small open economy, Economica, vol. 58, p. 515-529.

Davidson, Larry S. (1999) Choice of a proper methodology to measure quantitative and qualitative effects of the impact of sport, Dans The Economic Impact of Sport Events, Neuchâtel, sous la direction de Jeanrenaud, Claude, p.28-44, Neuchâtel : Editions CIES.

Davezies Laurent (2008) La république et ses territoires. La circulation invisible des richesses, Paris : Seuil. $112 \mathrm{p}$.

Dion, Yves (1987) «Le multiplicateur régional appliqué à un espace économique de petite dimension ». Thèse de doctorat, Bordeaux: Université de Bordeaux I. $264 \mathrm{p}$.

Doucet, Carole (2002) «Activités viticoles et développement régional ». Thèse de doctorat en science économique, Bordeaux: Université de Montesquieu Bordeaux IV. 352 p.

Dwyer, Larry; Peter Forsyth et Ray Spurr (2003) «Inter-industry effects of tourism growth: implications for destination managers », Tourism Economics, vol. 9, $n^{\circ} 2$, p. 117-132.

ESSEC - Chaire européenne de marketing sportif (2007) Les retombées économiques de la Coupe du monde de rugby 2007 en France, étude pour le Comité d'organisation France 2007, Paris, 27 avril 2007.

Gouguet, Jean-Jacques (1981) «Pour une réhabilitation de la théorie de la base », Revue d'économie régionale et urbaine, no 1, p. 63-83.

Jeanrenaud, Claude (dir.) (1999) The Economic Impact of Sport Events, Neuchâtel: Editions CIES. 210 p.

Kasimati, Evangelia (2003) «Economic aspects of the Summer Olympics: a review of related research ", International Journal of Tourism Research, vol. 5, n ${ }^{\circ} 6$, p. 433-444.

Papeles de Europa

25 (2012): 27-50

Doi: http://dx.doi.org/10.5209/rev_PADE.2012.n25.41094 
Barget, Eric and Gouguet, Jean-Jacques. The importance of foreign spectators' expenditure in the tourism impact of mega-sporting events.

Kesenne, Stephan (2005) «Do we need an economic impact study or a cost-benefit analysis of sports event? », European Sport Management Quarterly, vol. 5, $\mathrm{n}^{\circ} 2$, p. 133-142.

$\mathrm{Li}$, ShiNa et Adam Blake (2009) «Estimating Olympic Related Investments and Expenditure », International Journal of Tourism Research, vol. 11, $n^{\circ} 4$, p. 337356.

Madden, John Robert (2002) «The Economic Consequencies of the Sydney Olympics ", The CREA/Arthur Andersen Study, Current Issues in Tourism, vol. $5, \mathrm{n}^{\circ} 1, \mathrm{p} .7-21$.

Mankiw, Gregory (1998) Principes de l'économie, Paris : Economica. 972 p.

Martin, Fernand (1991) «Faiblesses, embûches et abus dans les analyses avantages-coûts de projets ", Revue canadienne d'études du développement, vol. $12, \mathrm{n}^{\circ} 1$, p. 90-105.

MKG HOSPITALITY (2007) Bilan de la Coupe du Monde de Rugby: l'hôtellerie française sort gagnante, communiqué de presse, 24 octobre, Paris.

Perret Bernard (2004) Évaluation des politiques publiques, Paris : La Découverte. $126 \mathrm{p}$.

Porter, Philip et Deborah Fletcher (2008) «The Economic Impact of the Olympic Games: Ex-ante Predictions and Ex-poste Reality », Journal of Sport Management, vol. 22, $\mathrm{n}^{\circ} 4$, p. 470-486.

Preuss, Holger (dir.) (2006) «Special Issue: Impact and Evaluation of Major Sporting Events », European Sport Management Quarterly, vol. 6, n 4, p. 313415.

Preuss, Holger (2007a) «The Conceptualisation and Measurement of Mega Sport Event Legacies », Journal of Sport and Tourism, vol. 12, $n^{\circ}$ 3-4, p. 207-227.

Preuss, Holger (2007b) «FIFA World Cup 2006 and its Legacy on Tourism », DANS Trends and Issues in Global Tourism, sous la direction de Roland Conrady et Martin Buck, p. 83-103. Berlin : Springer.

Ritchie, J. R. Brent et Ju Yangzhou (1987) The role and impact of mega-events and attractions on national and regional tourism development: a conceptual and methodological overview, DANS Proceedings of the $37^{\text {th }}$ annual congress of the international association of scientific experts in tourism (AIEST), p. 17-58, Calgary.

Stringer Yvon (1993) «Le mirage des retombées économiques », DANS L'analyse coûts-avantages - Défis et controverses, sous la direction de G. Gauthier et M. Thibault, p. 335-350., Paris : Economica, coll. « Gestion ».

Teed, K.C. (2006) « Mega-events, sport tourism, and the Olympic Games », Tourism Review International, vol. 10, p. 205-206.

U.R.S. FINANCE AND ECONOMICS (2004) Economic Impact of the Rugby World Cup 2003, pour le Département de l'Industrie, du Tourisme et des Ressources, Melbourne.

Vollet, Dominique et Jean-Paul Bousset (2002) «Use of Meta-analysis for the Comparison Transfer of Economics Base Multipliers », Regional Studies, vol. $36, n^{\circ} 5$, p. 481-494. 